\title{
Assessment of Plants at Petroleum Contaminated Site for Phytoremediation
}

\author{
Raymond Oriebe Anyasi ${ }^{1}$, Harrison Ifeanyichukwu Atagana ${ }^{2}$ \\ ${ }^{1}$ Department of Environmental Sciences, University of South Africa \\ Pretoria, South Africa 0003 \\ ${ }^{2}$ Institute for Science and Technology Education, University of South Africa \\ Pretoria, South Africa 0003 \\ eanyasr@unisa.ac.za; Atagahi@unisa.ac.za
}

\begin{abstract}
The study is aimed at identifying native plants growing around petroleum hydrocarbon contaminated site in Umuahia, Nigeria that has the ability to phytoremediate the contaminant from the soil. A total of 28 native plants in the area were sampled. Most of the plants demonstrated the ability to grow in a high concentration of the total petroleum hydrocarbon which is an indication that they can be used for phytoremediation of a petroleum hydrocarbon contaminated soil. Chromolaena odorata, Aspilla africana, Chloris babata, Pasparlum vaginatum, Bryophylum pinnatum, Paspalum scrobiculatum, Spondias mombim, Euragrostis atrovilens, Cyperus rotundus, Uvaria chamae all demonstrated phytoremediation characteristics in the contaminated site. Among those characteristics was the ability to survive the toxic nature of the contamination and to uptake part of the contamination. Pearson correlation demonstrated a significant and positive relations $(r=0.64, p=0.003)(p<0.05)$ between the soil and root TPH. Using bioaccumulation factor as a module for phytoremediation resulted in Linear regression between TPH concentration in the soil and root tissue of $\mathrm{Y}=1.8696 \mathrm{x}+$ 608.55. From this study, chromolaena odorata, Aspilla Africana and Uvaria chamae were selected as candidate plants for phytoremediation of PAHs.
\end{abstract}

Keywords: Native plants, contaminated sites, PAHs, TPHs, Phytoremediation, Organic compounds.

\section{Introduction}

Incessant human activities causing the release of large amounts of toxic compounds into the soil. These compounds that include heavy metals, metalloids as well as organic pollutants causes threats to the environment as they accumulate in soil and are readily passed unto man and animals through the food chain [1]. This lack of control in the contamination of the environment called for the need in the provision of appropriate measures to control or curtail the effects of those contaminations. The issue of environmental pollution is a global problem which has drawn a major concern since the recent past. Just as different contaminants predominates at different areas so will unique methods of management and control be employed based on what is obtainable in such areas [2].

Phytoremedition has been shown to be the most efficient and environmentally friendly means of restoring original soil conditions when contaminated by environmental organic contaminants [3]. The technology is generally accepted as the proven technology for the removal of environmental contaminants due to its minimal energy requirement and the beauty of the technique [1,3]. PAHs are group of highly toxic and recalcitrant organic compounds that are distributed widely in the environment. The problem of incomplete biodegradation of the higher molecular weight PAHs has been impacting in nature leading to various health effects to human and the animals [4]. However, plants have shown the ability to take up most of these PAHs and their toxic metabolites. This forms the major entry route of the compound into the food chain and the effects is been felt in almost every part of the ecosystem [5].

The biological action of plants has demonstrated an encouragement for organic contaminant reduction. It ultimately provides an enabling environment for microbial proliferation at the root area of the plant known as rhizodegradation. This phenomenon is possible as a result of the symbiotic relationship between plant and the microorganism, which is usually triggered by the unique properties of the plant [6-7]. Different plants have been used for the remediation of various environmental contaminants. And in all of those studies, the plants tested were able to present a successful phytoremediations effects towards the contaminants. Some plants have been used as a phytoaccumulator of metals [8], at 
the same time various plants have identified as good phytoremediators of organic contaminated environment3,9-10. Most specifically some have also been for the phytoremediation of PAHs [11-12].

However, there is little information with regards to what plant could be used at what area and why. Therefore the aim of the study encompasses identification of natives plants found to be growing in a PAHs contaminated soil at the Umuahia petroleum pipeline track, which has been previously vandalized allowing the flooding of the area with petroleum products. Total petroleum hydrocarbon (TPH) which has always been the primary criterion for environmental assessment of petroleum industries was measured in the area. And the level was found to be at a high threshold. Meanwhile the fact that some plants were still growing at the site means that such plants could have certain parameters that could of important for the management of PAH contaminated soil.

\section{Materials and Methods}

The study was conducted in Umuagu village located along the Portharcourt-Aba-Umuahia-Enugu Expressway a few kilometres from Umuahia in Abia state of Nigeria. The area lies within Latitude. $5^{\circ} 35^{\prime} 59.99^{\prime \prime} \mathrm{N}$ and Longitude $7^{\circ} 31^{\prime} 59.99^{\prime \prime} \mathrm{E}$ (Figure 1). It is an area that has faced multiple vandalization of petroleum pipeline with subsequent waste of refined petroleum products at the pipe line channel from the south eastern part of Nigeria to the rest of the country. Sampling of the soil at the contaminated site was carried out and the TPH concentration of the area was measured.

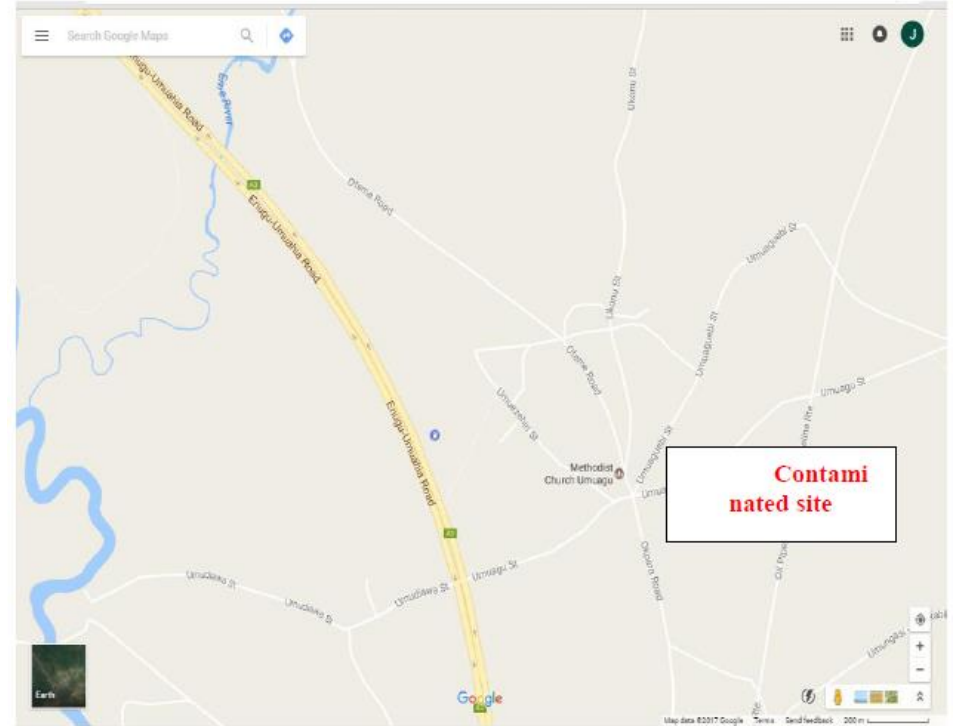

Fig. 1: Satelite map of Umuahia in Nigeria showing the study area and sample site 5³5'59.99" N 7³1'59.99" E (Google map).

\section{How to Calculate the Biological Accumulation Coefficient (BAC) Values}

$\mathrm{BAC}$ is a factor established so that we could measure how plant is able to uptake compounds from a substrate. This phenomenon is based on the equation bellow:

$$
B A C=\frac{\text { Concentration in plant tissue }\left(\frac{\mathrm{mg}}{\mathrm{kg}}\right)}{\text { Concentration in soil }\left(\frac{\mathrm{mg}}{\mathrm{kg}}\right)}
$$

Results derived from the determination of BAC are always being matched with plants categories so as to be able separate plants as hyperaccumulator or not (Table 2). This was determined using the metal uptake level of different plants. However, the same protocol can also be used to measure for the BAC of plants on organic contaminants. 
Table 1: Category of BAC values in plants [13].

\begin{tabular}{|l|l|}
\hline Plants category & Range \\
\hline High accumulator plants & $1.0-10$ \\
\hline Moderate accumulator plants & $0.1-1.0$ \\
\hline Low accumulator plants & $0.01-0.1$ \\
\hline Non accumulator plants & $<0.01$ \\
\hline
\end{tabular}

\section{Laboratory Analysis}

Sludge preparation: Soil samples were air dried at room temperature for two weeks, homogenized with hand and pounded using a mortar, sieved through $1.00 \mathrm{~mm}$ mesh. This selection was done so as to encourage homogeneity of the mixture.

\section{Extraction of the Soil for TPH Analysis}

To carry out the extraction of soil for TPH analysis, USEPA [14] method of ultrasonic extraction method was used and amended. $10 \mathrm{~g}$ of the soil mixture sample was placed in a $250 \mathrm{Ml}$ volumetric flask and was mixed with approximately $4 \mathrm{~g}$ sodium sulfate ( $\mathrm{Na} 2 \mathrm{SO} 4)$. The sodium sulphate acted as a dehydrating agent as the presence of water to alter the measure of the TPH. Final analysis of the TPH was done using Agilent 6890 Plus gas chromatograph equipped with a micro-63 Ni electron capture detector, an SPBTM-1 fused silica capillary column $(30 \mathrm{~m}, 0.25 \mathrm{~mm}$, ID x $0.25 \mu \mathrm{m}$ film thickness) and HPChem station software. Data were collected in selective ion monitoring mode [15]. The injector and detection temperature was kept at 340 and $380 \mathrm{oC}$ respectively. And the oven temperature was programmed at $420 \mathrm{oC}$ held for $4 \mathrm{~min}$ and ramped at $10 \mathrm{oC}$ per min to 340 and held for 12 mins. The carrier gas used was helium at a flow rate of 1.00 $\mathrm{mL}$ per min. the total analysis was about 40 mins.

$2 \mu \mathrm{L}$ of the extract was injected into the GC to obtain the chromatogram of the TPH. The quantification was done with a five point's calibration plot (1, 5, 10, 20,50 mgL-1) of the aliphatic hydrocarbon ranges from C8 to C40. Quantitation for each carbon number was done by summarizing the area for each carbon number at the respective retention time and correlated with the area for individual carbon number of the calibration standards.

\section{Elementary Analysis of the Soil}

The EPA 3051 methods of extraction using Aqua Regia (AR) procedure [16], with a concentrated acid in a microwave oven, under controlled temperature and pressure was used. AR: $0.5 \mathrm{~g}$ of soil samples sieved through $100 \mathrm{mesh}$ was transferred to Teflon tubes. Each tube received $9 \mathrm{ml}$ of concentrated $\mathrm{HCl}(32 \%)$ and $3 \mathrm{ml}$ of concentrated $\mathrm{HNO} 3(65 \%)$ (3:1) of analytical-level purity, and the mixture was left undisturbed for $12 \mathrm{~h}$ of pre-digestion. The tubes were subsequently placed in a closed system in a microwave oven (Mars Xpress, CEM Corporation) for 20 min at $180{ }^{\circ} \mathrm{C}$ subsequently passing the temperature ramp. After cooling, samples were transferred to certified 25-ml flasks (NBR ISO/IEC), the flask volume was completed with ultrapure water, and the extracts were filtered. All analyses were carried out with three replicates [8.] Calibration curves to determine metal concentrations were prepared based on 1,000 $\mathrm{mgL}^{-1}$ standards, using ultrapure water for dilution, cleaning, and decontamination of the glassware, which was kept in $10 \%$ nitric acid solution for $24 \mathrm{~h}$ and rinsed with distilled water and ultrapure water. Concentrations of $\mathrm{Co}, \mathrm{Cr}, \mathrm{Cu}, \mathrm{Ni}, \mathrm{Pb}$, and $\mathrm{Zn}$ were determined via atomic absorption spectrophotometry (FAAS) and Cd concentrations in a graphite oven. However, methods in which a closed system is heated with a microwave oven are well established and widely employed [17]. 
Table 2: Average contents of heavy metals recovered for certified reference material.

\begin{tabular}{|l|l|l|l|l|}
\hline Elements & Soil system & Recovery level & Certified value & Percentage recovery \\
\hline $\mathrm{Cd}$ & Soil mixture & 0.45 & $0.07 \pm 0.002$ & 111 \\
\hline $\mathrm{Co}$ & “ & 11.3 & $12.80 \pm 0.2$ & 76 \\
\hline $\mathrm{Cr}$ & “ & 55.0 & $130.0 \pm 9.0$ & 43 \\
\hline $\mathrm{Cu}$ & “ & 27.2 & $33.0 \pm 0.05$ & 75 \\
\hline $\mathrm{Ni}$ & 32.4 & $85.0 \pm 2.0$ & 73 \\
\hline $\mathrm{Pb}$ & “ & 11.0 & $17.3 \pm 0.1$ & 50 \\
\hline $\mathrm{Zn}$ & “ & 74.2 & $103.0 \pm 4.0$ & 72 \\
\hline
\end{tabular}

\section{Plants}

Preparations: Before the commencement of the analysis plant samples were washed with tap water and rinsed with distilled water to remove adhering soil particles. Afterwards the samples were dried at room temperature for 48 hours and were then ground into powder using mortar and pestle after the weighing. The powdered sample was then used for analysis.

Extraction of metals from the soil: The methods used was wet digestion, the powdered plant samples was placed in a $100 \mathrm{~mL}$ cornical flask and added with $10 \mathrm{~mL}$ of conc HNO3. The flask was covered with a glass cover and was allowed to stand overnight until the entire bubbles were dispersed. Afterwards, the sample was heated in a hot plate for $1 \mathrm{hr}$ at $120 \mathrm{oC}$. Distilled water was then added to enable complete digestion. When that is done, the flask was cooled and about $1 \mathrm{~mL}$ of $\mathrm{H}_{2} \mathrm{O}_{2}$ was added, and returned to a hot bath for continuous heating with intervally addition of $\mathrm{H}_{2} \mathrm{O}_{2}$ for every 4-8 mL of solution lost until digested sample becomes clear. Glass cover was then removed and temperature reduced to about $80^{\circ} \mathrm{C}$. The digestion was continued until the samples become dried, and is then cooled. On cooling, $2 \mathrm{~mL}$ of acid mixture 1:3 $\mathrm{HNO}_{3}-\mathrm{HCl}$ was added, and the mixture filtered using a filter paper and afterwards analysed using ICP-OES (Perkin Elmer, USA).

\section{Root Tissue Comparison Analysis}

To establish the reason behind the high BAC of some of the plants growing in the contaminated site, root tissues from two species from each family of plants were selected analyzed for their carbon and lipid contents. Prior to analysis, the root tissues were air dried on at room temperature for one week. The air-dried root tissues were hand broken and then ground into powder using mortar and pestle. Carbon and lipid content was determined using Orita (2012) method.

\section{Lipid Analysis}

The lipid content of the root tissue was determined by extracting $2 \mathrm{~g}$ dry root tissue with ethyl ether for 24 hours in a Soxhlet apparatus. Lipid content was calculated by dividing the extracted lipid weight by the dry tissue weight added to the thimble. Fresh tissue lipid content was then calculated by multiplying the dry lipid content by the fractional water content.

To ensure quality control, all reagents used were of analytical grade and were used without further purification. All the glass wares were totally sterilized, and the analysis was one in triplicates.

\section{Results}

In the profiling of the plants, results showed that there were 5 families and 13 species that dominated the entire flooded area. Astericeae family which are shrubs was the most dominant. In the area outside the oil contaminated site, there were 9 species from 8 different families that were identified. The greater number of species in the non-contaminated site indicated the natural state of the area.

The Astericeae family which are shrubs were the dominant plants at 31\%, followed by Gramineae (29\%), Cyperaceae (which could also be called legumes) (17\%) and Leguminoceae (8\%) (Figure 2 and Table 4). The rest with lesser dominant approach were Malvaceae, Euphobiaceae, Pteridophyte, Onagraceae, Sterculiaceae, Melastomaceae each with (2 \%), while Vitaceae, Anacardiaceae and Annonaceae were all had $1 \%$ each. Although Anacardiaceae and Annonaceae 
had lesser dominance, they however, seconded Asteraceae families in their ability to phytoaccumulate PAHs, hence were included in the induced phytoremediation study.

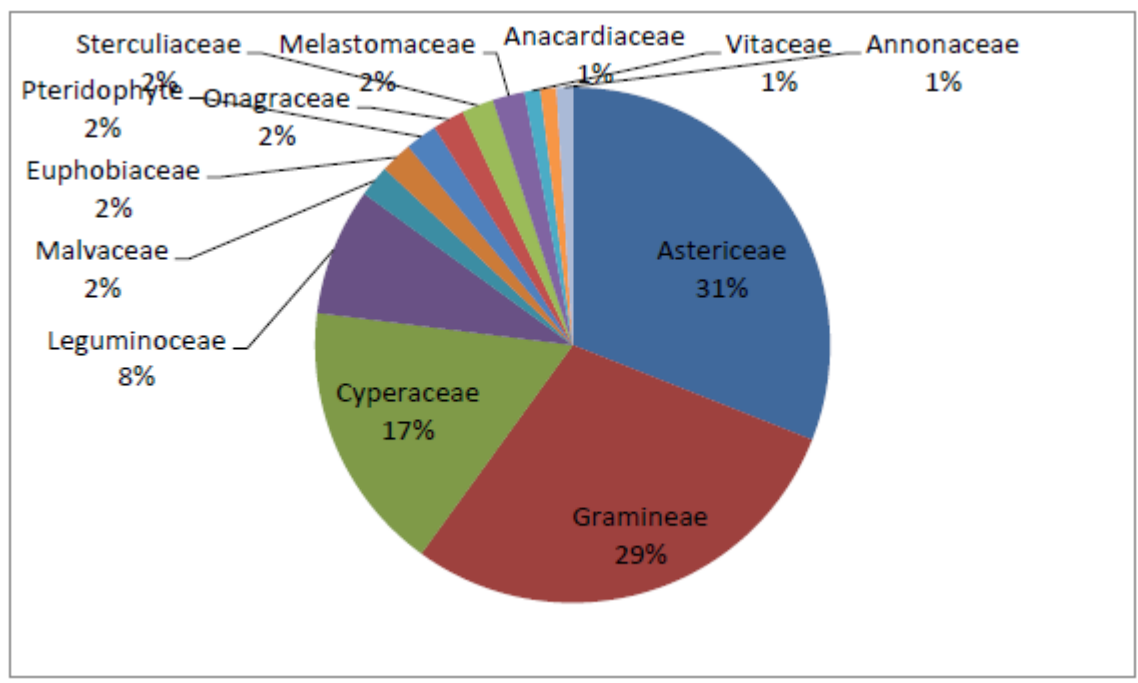

Fig. 2: Plant families sampled and their percentage dominance.

Table 3: Plant species samples at the petroleum contaminated site in Umuahia, Nigeria.

\begin{tabular}{|l|l|}
\hline Family & Specie \\
\hline Asteraceae & $\begin{array}{l}\text { Chromolaena odorata, Aspilla Africana, Chrysocoma ciliate, Dimorphotheca } \\
\text { pisifera, Cosmos bupinnatus, Teraxacum sp. }\end{array}$ \\
\hline Gramineae & $\begin{array}{l}\text { Orinus longiglumis, Paspalum scrobiculatum, Paspalum vaginatum, Chloris } \\
\text { babata }\end{array}$ \\
\hline Vitaceae & Cayratia eurynemia \\
\hline Malvaceae & Steculia Africana, Sterculia urceolata \\
\hline Cyperaceae & Cyperus rotundus, Cyperus esculentus, Carex stricta, Scirpus cespitosus \\
\hline Anacardiaceae & Buchanania acuminata \\
\hline Euphobiaceae & Sabastiana chamaelea, Dysopsis Baill \\
\hline Annonaceae & Uvaria chamae \\
\hline Pteridophyte & Cyperus difformis, Salvinia natans \\
\hline Onagraceae & Calylophus beriandieri, Calylophus serrulatus \\
\hline Leguminoceae & Vigna marina, Vigna unbellata \\
\hline Sterculiaceae & Melochia corcholifolia \\
\hline Melastomaceae & Melastoma malabathricum \\
\hline
\end{tabular}

\section{Plant Variations and Screening of Potential Plants as Phytoremediator for PAHs.}

For phytoremediation of organic contaminations site to be possible, plants must germinate, survive and grow in that atrocious condition. This is the only condition that could make such plant to be considered as a potential plant for phytoremediation [18]. The plant is resistant when it is able to survive and reproduce under contaminated soil condition. There are factors responsible for this phenomenon, and they include metabolic changes, hormone production and enzymes sequestration triggering substrate concentration and enzyme activity.

At a high concentration of TPH in the soil, C. odorata, A. Africanus, C. ciliate, C. bipinatus, P. vaginatum, C. babata, E. atrovirens, B. acuminate, $U$. chamae, were able to survive the harsh condition of the concentration (Table 5). $C$. odorata, B. acuminate and U. chamae demonstrated the ability to grow at the highest TPH contaminated condition which according to the site ranges from 329-214,241,373-8011, 274-6318 mg/kg respectively. 
Table 4: Concentration of TPH in soil taking from the rhizosphere area of the plants in the contaminated site.

\begin{tabular}{|c|c|c|c|}
\hline Plant species & $\begin{array}{l}\text { TPH concentration in soil } \\
(\mathrm{Mg} / \mathrm{kg})\end{array}$ & $\begin{array}{l}\text { TPH in plant tissues } \\
(\mathrm{Mg} / \mathrm{kg})\end{array}$ & $\begin{array}{l}\% \\
\text { absorbed }\end{array}$ \\
\hline C. odorata & $329-214,241$ & $8.5-2235$ & Root \\
\hline A. africanus & $163-4264$ & $0.5-18.9$ & Root \\
\hline C. ciliata & $105-1970$ & $0.05-4.0$ & Root \\
\hline D. pisifera & $328-1714$ & $0.5-2.4$ & Root \\
\hline C. bipinatus & $277-5928$ & $0.5-30.0$ & Root \\
\hline O. lungighumis & $149-510$ & ND & Root \\
\hline P. scrobiculatum & $235-2993$ & $. .3-7.5$ & Root \\
\hline P. vaginatum & $210-3017$ & $0.04-2.7$ & Root \\
\hline C. babata & 291-1168 & ND & Root \\
\hline C. eurynemia & $59-1235$ & 0.5 & Root \\
\hline S. africana & $19-402$ & ND & Root \\
\hline S. urceolata & $121-3299$ & $0.05-1.2$ & Root \\
\hline C. rotundus & $275-3664$ & $1.3-4.2$ & Root \\
\hline C. esculentus & $232-2611$ & $0.2-0.9$ & Root \\
\hline C. stricta & $672-5232$ & $0.4-12.0$ & Root \\
\hline S. cespitasus & 659 & ND & Root \\
\hline S. chamaelea & $67-538$ & ND & Root \\
\hline D. baill & $97-2009$ & $0.3-0.5$ & Root \\
\hline C. difformis & 448 & ND & Root \\
\hline S. natans & 79 & ND & Root \\
\hline C. beviandieri & $107-276$ & ND & Root \\
\hline C. serrulatus & 140 & ND & Root \\
\hline V. marina & $48-176$ & ND & Root \\
\hline V. umbellata & $32-94$ & ND & Root \\
\hline M. corcholifolia & $46-312$ & ND & Root \\
\hline M. malabatricum & $39-1556$ & 0.28 & Root \\
\hline C. acuminata & $373-8011$ & $2.1-36.4$ & Root \\
\hline U. chamae & $274-6318$ & $1.8-30.1$ & Root \\
\hline
\end{tabular}

$\mathrm{ND}=$ not ditected

\section{Assessment of the Root System of the Plants Growing in the Contaminated Site}

The plants samples that demonstrated the ability to withstand the severity of high contamination of PAH in the petroleum contaminated site were found to possess fibrous rooting system able to spread across a large surface area. Most importantly, all the 3 selected plants that grew at high concentration of TPH all have fibrous root systems. Fibrous root system is known to support high colonization of soil microorganism, due to the large surface it generates. This is one of the qualities of plants that could be used for the cleaning of a petroleum hydrocarbon contaminated environment [18].

\section{Distribution of TPH in Soil and Plants}

The range of TPH of soil in the contaminated soil at the site varied between 0.5 to $3110 \mathrm{mg} / \mathrm{kg}$, with a mean value of 1493.1. The concentration of TPH in the plant roots analysed ranges from $1100-8500 \mathrm{mg} / \mathrm{kg}$ with a mean value of $3400 \mathrm{mg} / \mathrm{kg}$. The standard deviation of soil was 1013.2 and that of plant root was 2371.5, giving an indication of high variation in both the soil depth and the plant root. 


\section{Correlation Matrix}

The relationship that existed between the concentration of TPH in soil and plants tissues was examined using correlation analysis (Table 7). According the Pearson correlation, a significant and positive relations $(r=0.64, p=0.003)$ (significant level at $\mathrm{p}<0.05$ ) between the TPH concentration in depth of soil and root. The reason behind this might be that the increase of TPH in the soil also increases the uptake of PAH by the plants.

In the linear regression between TPH concentration in the soil depth and root tissue concentration indicated a linear model as described below:

$$
Y=1.8696 x+608.55
$$

\section{Discussions}

From the result received, the family of plant that dominated in the contaminated site were Astericeae, Gramineae, Cyperaceae, and Leguminoceae. The rest with lesser dominant approach were Malvaceae, Euphobiaceae, Pteridophyte, Onagraceae, Sterculiaceae, Melastomaceae, while Vitaceae, Anacardiaceae and Annonaceae were scattered. Apart from the dominance presence of these plant, only Asteraceae, Anacardiaceae, and Annonaceae families that demonstrated the greater ability to phytoaccumulate PAHs. These sets of plants belong to the grass and legume family. It is reported in literature that grasses and legumes has high potential to remediate PAHs [19]. In the study done by Idris and his coscholars to identify sets of plants at a petroleum contaminated site in Malaysia that could be suitable for phytoremediation, the dominated plants as was reported in that study to belong to the family of legumes and grasses7. The clear explanation to this could be the presence of extensive fibrous root system with diverse root surface area, hence can penetrate deep down into the soil.

Literature reports indicated that success of phytoremediation of environmental contaminants both organic and inorganic has been achieved with the following plants: Poplar tree (Populus deltoides), Willow (Salix species), Indian mustard (Brassica juncea L.), Indian grass (Sorghastrum nutans), and Sunflower (Helianthus Annuus L.) [3,20]. This success is as a result of their diverse root system that enabled even microbes an environment for successful growth, and also absorption of large quantities of water [21].

Optimal growth of plant in the contaminated soil is significant for phytoremediation to be possible. But for plant to grow in a contaminated environment it must have to severe the phytotoxic nature of the contamination, hence such plant should be able to germinate, survive and grow in such harsh condition [22]. There was high growth incidence of the selected plants at the contaminated site even at the high concentration of TPH. This means that such plant were able to resist the contamination of the petroleum products dispersed over the soil. For plants to resist the obnoxious condition of a PAH contaminated environment, it has to undergo metabolic changes resulting in hormone production and enzyme sequestration which brings about substrate modification and increased enzyme activity [23]. The toxicity of hydrocarbons is as a result of its volatility and hydrophobicity. Low molecular weight hydrocarbons which are mostly volatile have the tendency to move easily through cell membranes, resulting in their toxicities [7,24]. However, the presence of oil in the hydrocarbons causes less water infiltration and aeration required for optimal growth and development of plants, but most of the plants in this study were able to survive such toxicity.

There was high standard deviation in both the soil sample and the root of the plant showing a high deviation in their concentrations. High value of root TPH in plants explains the fact that there was high absorption of petroleum hydrocarbon by the roots. The proportion of the concentrations of TPH in both soil and plants shows that absorption and accumulation of petroleum hydrocarbon in plants depends on the concentration of the pollutant in the environment which in this case is the soil. The accumulation of high content of the contaminant resulted in the spillage of the petroleum products resulting from the vandalization of petroleum product pipeline in the area. The mean value of TPH in the soil exceeded the permissible limit of global TPH in soil $(1000 \mathrm{mg} / \mathrm{kg})$, indicating a high concentration of PAH in the site. Furthermore, the average value of the plant tissue TPH exceeded that global permissible limit in soil, but the value was within the phytotoxic level in plant $(1000-12000 \mathrm{mg} / \mathrm{l})$. This result is in agreement with that of Lotfinasabasl et al. [25], that documented a high TPH values in soil and plants sampled in that soil as a result of an oil spill event.

From the result of the BAC of the plants, it was indicated that some of the plants tolerated the high concentration of TPH in the contaminated site. The value of BAC in plants usually expresses the accumulation capability of toxicants by plant in relation to such contaminants bioavailability in soil [26]. The ability of the plants in the sampled site to tolerate the high concentration of TPH is an indication that the plants are potential hyperacumulator plants for petroleum 
hydrocarbons. This was demonstrated by the significant and positive relations between the TPH concentration in depth of soil and root during correlation and regression analysis. To assess which plants have the most potentials, further tests done presented plants from the family of Asteraceae, Anacardiaceae, and Annonaceae as those plants. These plant species belong to the shrubs and grass category of plants. Idris et al. [7] reported high BAC values in shrubs and grasses with fibrous root systems. Although plants TPH was assessed only in the root tissues of the plants in this study, authors further study involved the assessment of the value in the entire plant tissues (stem and leaf). Because this study only concentrated in the plants screening, translocation abilities of the plants were not recorded.

\section{Conclusions}

The result of this study involving the screening of plants at a petroleum hydrocarbon contaminated site in Umuahia-Nigeria, presented C. odorata, B. acuminate, and $U$. chamae as potential plants for phytoremediation of $\mathrm{TPH}$. These plant species were able to grow in that contaminated site with high TPH values possessing other factors of a good phytoremediation plants as reported in literature. About 8 plant species could suffice as potential TPH phytoremediator as was recorded by their degree of growth; the plants included C. odorata, A. Africanus, C. ciliate, $C$. bipinatus, $P$. vaginatum, $C$. babata, E. atrovirens, B. acuminate, U. chamae. BAC factors were used to select the potential plant absorption of PAHs and to be able to determine which plant serves the most potential for phytoremediation of organic contaminated soil. The entire assessment of the screened plants in the contaminated site demonstrated good potentials for petroleum hydrocarbon remediation. Since phytoremediation has been reported as the most preferred method of contaminant remediation, the sampled plant could be used with amendments for ecosystem protection.

\section{Acknowledgement}

The authors wish to acknowledge the financial contribution of the National Research Foundation of South Africa (NRF).

\section{References}

[1] L. T. Danh, P. Truong, R. Mammucari, T. Tran, N. Foster, "Vétiver grass, Vetiveria zizanioides: A choice plant for phytoremediation of heavy metals and organic wastes," Int J Phytorem, vol. 11 no. 8, pp. 664-691, 2009.

[2] P. L. Gratão, C. C. Monteiro, R. F. Carvalho, T. Tezotto, F. A. Piotto, L. E. P. Peres, R. A. Azevedo, "Biochemical dissection of diageotropica and Never ripe tomato mutants to Cd-stressful conditions," Plant Physiol Biochem, vol. 56, pp. 79-96, 2012.

[3] B. V. Aken, P. A. Correa, J. L. Schnoor, "Phytoremediation of polychlorinated biphenyls: new trends and promises," Environ Sci Technol, vol. 44 no. 8, pp. 2767-2776, 2010.

[4] S. Cherian, M. M. Oliveira, "Transgenic Plants in Phytoremediation: Recent Advances and New Possibilities," Environ Sci Technol, vol. 39 no. 24, pp. 9377-9390, 2005.

[5] K. Sun, L. Liu, L. Jin, Y. Z. Gao, "Utilizing pyrene-degrading endophytic bacteria to reduce the risk of plant pyrene contamination," Plant Soil, vol. 374, no. 1, pp. 251-262, 2014.

[6] M. McGuinness, D. Dowling, "Plant-associated bacterial degradation of toxic organic compounds in soil," Int J Environ Res Public Health, vol. 6, no. 8, pp. 2226-2247, 2009.

[7] M. Idris, S. R. S. Abdullah, H. S. Titah, M. T. Latif, A. R. Abasa, A. K. Husin, R. F. Hanima, R. Ayub, "Screening and identification of plants at a petroleum Contaminated Site in Malaysia for Phytoremediation," J Environ Sci Manage, vol. 19, no. 1, pp. 27-36, 2016.

[8] L. A. Souza, F.A. Piotto, R.C. Nogueirol, R.A. Azevedo, "Use of non-hyperaccumulator plant species for the phytoextraction of heavy metals using chelating agents," Scientia Agricola, vol. 70, no. 4, pp. 290-295, 2013.

[9] D. Shim, Y-I. Choi, J. Park, S. Kim, J-U. Hwang, E-W. Noh, Y. Lee, "Engineering poplar plants for phytoremediation," 2016. [Online]. Available: http://www.niaes.affrc.go.jp/marco/marco2009/english/.../W105_LeeYoungsook.

[10] N. Orita, "Root uptake of organic contaminants into plants: Species differences," M.S. dissertation, Utah State University, USA, 2012. 
[11] S. L. Doty, "Enhancing phytoremediation through the use of transgenics and endophytes," New Phytol, vol. 179, no. 2, pp. 318-333, 2008.

[12] R. Vácha, J. Čechmánková, J. Skála, "Polycyclic aromatic hydrocarbons in soil and selected plants," Plant Soil Environ, vol. 56 no. 9, pp. 434-443, 2010.

[13] C. L. Bini, L. Gentili, B. Maleci, O. Vaselli, "Trace elements in plant and soils of urban parks," Annexed to contaminated soil prost. INRA, Paris, 1995.

[14] USEPA: Method 3550C, Ultrasonic Extraction, United States Environmental Protection Agency, SW-846 Manual," U.S. Government Printing Office; Washington, (DC), 2007. [Online]. Available: http://www.epa.gov

[15] M. L. Whitfield Aslund, B. A. Zeeb, A. Rutter, K. J. Reimer, "In situ phytoextraction of polychlorinated biphenyl(PCB) contaminated soil," Sci Total Environ, vol. 374, no. 1, pp. 1-12, 2007.

[16] S. P. McGrath, C. H. Cunliffe, "A simplified method for the extraction of metals $\mathrm{Fe}, \mathrm{Zn}, \mathrm{Cu}, \mathrm{Ni}, \mathrm{Cd}, \mathrm{Pb}, \mathrm{Cr}, \mathrm{Co}$ and Mn from soils and sewage sludges," J Sci Food Agric Bark, vol. 36, no. 9, pp. 794-798, 1985.

[17] S. Sakan, D. Đorđević, G. Dević, D. Relić, I. Anđelković, J. Đuričić, "A study of trace element contamination in river sediments in Serbia using microwave-assisted aqua regia digestion and multivariate statistical analysis," Microchem J, vol. 99 no. 2, pp. 492-502, 2011.

[18] A. M. Idris, I. Al-tahir, E. Idris, "Antibacterial activity of endophytic fungi extracts from the medicinal plant Kigelia Africana," Egypt Acad J Biolog Sci, vol. 5, no. 1, pp. 36-44, 2013.

[19] P. E. Ndimele, "A review on the phytoremediation of petroleum hydrocarbon," Pakistan J Biol Sci, vol. 13, no. 15, pp. 715-722, 2010.

[20] B. R. Glick, J. C. Stearns, "Making phytoremediation work better: maximizing a plant's growth potential in the midst of adversity," Int J Phytorem, vol. 13, no. 1, pp. 4-16, 2011.

[21] R. O. Anyasi, H. I. Atagana, "Enhancing growth performances of Chromolaena odorata in two soil samples by using cow manure as amendment," Pak J Bot, vol. 46, no. 5, pp.1771-1779, 2014.

[22] P. Tanhan, P. Pokethitiyook, M. Kruatrachue, R. Chaiyarat, S. Upatham, "Effects of soil amendments and EDTA on lead uptake by Chromolaena odorata: Greenhouse and field trial experiments," Int J Phytoremed, vol. 13, no. 9, pp. 897-911, 2011.

[23] A. A. Hoffmann, P. A. Parsons, Evolutionary genetics and environmental stress. Oxford University Press; Oxford, United Kingdom, 1991.

[24] E. Kaimi, T. Mukaidani, S. Miyoshi, M. Tamaki, "Ryegrass enhancement of biodegradation in diesel-contaminated soil," Environ Exp Bot, vol. 55, no. 1-2, pp. 110-119, 2006.

[25] S. V. Lotfinasabasl, R. Gunale, N. S. Rajurkar, "Petroleum Hydrocarbons Pollution in Soil and its Bioaccumulation in mangrove species, Avicennia marina from Alibaug Mangrove Ecosystem, Maharashtra, India," Int J Adv Res Technol, vol. 2, no. 2, pp. 1-7, 2013.

[26] A. Nagaraju, S. Karimulla, "Accumulation of elements in plants and soils in and around Nellore mica belt, Andhra Pradesh, India - a bigeochemical study," Environ Geo, vol. 41, no. 7, pp. 852-860, 2002. 